\title{
PEMBERDAYAAN MASYARAKAT PETAMBAK MELALUI PRODUK INOVATIF OLAHAN HASIL TAMBAK BERBASIS EKOWISATA MANGROVE DI KELURAHAN KEPUTIH, KECAMATAN SUKOLILO KOTA SURABAYA
}

\author{
Sri Wiyatiningsih ${ }^{*}$, Sigit Dwi Nugroho ${ }^{1}$, Wahyu Santoso² \\ ${ }^{1}$ Program Studi Agroteknologi, Fakultas Pertanian, UPN "Veteran" Jawa Timur \\ ${ }^{2}$ Program Studi Agribisnis, Fakultas Pertanian, UPN “Veteran” Jawa Timur \\ *E-mail Korespondensi: sri.wiyatiningsih@upnjatim.ac.id
}

\begin{abstract}
ABSTRAK
Nilai estetika dan spesifikasi, serta potensi keanekaragaman hayati merupakan alasan mengapa ekosistem mangrove layak dijadikan tujuan wisata. Masyarakat pesisir Keputih Kecamatan Sukolilo telah menyadari adanya kerusakan kawasan hutan mangrove di lingkungan mereka, dan mereka sudah meminta kepada Pemerintah Daerah untuk mengembalikan kondisi kawasan mangrove mereka seperti semula. Namun kurangnya kepercayaan diri dan kemampuan berusaha mereka menyebabkan mereka belum mampu bergerak sendiri. Pembelajaran dan pemberdayaan masyarakat Kelurahan Keputih Kecamatan Sukolilo dalam memahami dan menempatkan posisi dirinya sebagai masyarakat pesisir dalam pengembangan kawasan wisata mangrove sangat diperlukan. Konsep yang digunakan untuk mengatasi permasalahan adalah membangun kepercayaan dan kerjasama yang baik sehingga program ini dapat didukung oleh semua pihak. Kegiatan KKN PPM yang telah dilaksanakan adalah sosialisasi pentingnya tanaman Mangrove kepada siswa SD, SMA, petambak, nelayan, masyarakat, penyuluhan tentang pengembangan kawasan Ekowisata Mangrove, Green and Clean Kawasan ekowisata, Reboisasi Mangrove kepada masyarakat, pelatihan pengembangan teknologi olahan produksi hasil tanaman mangrove dan olahan produksi hasil laut/tambak, pembuatan kincir air untuk tambak, pelatihan pembibitan dan penanaman mangrove, pembuatan Alat Pengering Tepung Mangrove, pembuatan alat pengasapan bandeng, pelatihan manajemen pengembangan kewirausahaan, lomba Menggambar dan Mewarnai Tanaman Mangrove untuk anak SD, dan lomba Pengolahan hasil tanaman mangrove dan hasil tambak untuk Ibu-ibu PKK.
\end{abstract}

Kata kunci: Pemberdayaan masyarakat, produk inovatif, hasil tambak, ekowisata, mangrove.

\section{PENDAHULUAN}

Ekowisata mangrove merupakan salah satu alternatif sumber penghasilan bagi masyarakat diantaranya segi transportasi, pemandu wisata, pedagang, petambak, dan nelayan. Pemanfaatan ekosistem mangrove sebagai ekowisata harus direncanakan dengan baik, dan ini akan tercapai apabila sesuai dengan daya dukung lingkungannya. Nilai estetika dan spesifikasi, pendidikan dan penelitian, serta potensi keanekaragaman hayati merupakan alasan mengapa ekosistem mangrove layak dijadikan tujuan wisata (Anwar, 1998).

Hasil survei awal, wawancara, dan observasi lapang di Kelurahan Keputih, Kecamatan Sukolilo, diketahui bahwa masyarakat, yang secara spesifik sebagai masyarakat pesisir dengan berbagai mata pencaharian antara lain sebagai nelayan, petambak, buruh, dan pedagang, belum dapat menerima program pengembangan kawasan wisata mangrove menjadi suatu kawasan usaha mandiri dikarenakan kurangnya kepercayaan diri masyarakat akan kemampuan berusaha dari diri mereka sendiri. Selain itu pemahaman masyarakat terhadap pengembangan kawasan wisata mangrove menjadi suatu kawasan usaha mandiri, dengan tetap mempertahankan kawasan wisata yang berbasis pada pemeliharaan lingkungan masih sangat rendah. Hal ini terlihat dari kurangnya antusias masyarakat Keputih Kecamatan Sukolilo pada saat dilakukan survei dan wawancara tentang pengembangan kawasan ekowisata mangrove. Kondisi tersebut berbeda dengan masyarakat Wonorejo Kecamatan Rungkut yang telah lebih dahulu mengembangkan ekowisata mangrove dengan bantuan dan binaan dari Dinas Pertanian Kota Surabaya, namun demikian terlihat jelas kondisi kesejahteraan masyarakat di kedua wilayah tersebut berbeda. Masyarakat Wonorejo mempunyai tingkat kesejahteraan yang lebih baik (Nugrahanti, 2012).

Masyarakat pesisir Keputih Kecamatan Sukolilo telah menyadari adanya kerusakan kawasan hutan mangrove di lingkungan mereka karena dieksploitasi secara liar yang menyebabkan produksi ikan dan kepiting mereka berkurang, dan mereka sudah meminta kepada Pemerintah Daerah untuk mengembalikan kondisi kawasan mangrove mereka seperti semula. Namun kurangnya penguatan pemberdayaan dan pendampingan kepada mereka menyebabkan kepercayaan diri dan kemampuan berusaha mereka masih belum kuat (Wiyatiningsih, 2013). Dengan demikian, penguatan dan pemberdayaan masyarakat Kelurahan Keputih Kecamatan Sukolilo dalam memahami dan menempatkan posisi dirinya sebagai masyarakat pesisir dalam pengembangan usaha mandiri produk inovatif olahan hasil tambak berbasis 
wisata mangrove sangat diperlukan, dengan harapan masyarakat mampu meningkatkan kepercayaan dirinya untuk mengembangkan produk inovatif hasil tambak mandiri berbasis ekowisata mangrove.

Upaya peningkatan kepercayaan diri dan kemampuan usaha mandiri dalam pengembangan produk inovatif olahan hasil tambak masyarakat pesisir Kelurahan Keputih Kecamatan Sukolilo dilaksanakan melalui berbagai kegiatan pembelajaran dan pemberdayaan masyarakat dalam bentuk partisipasi masyarakat secara aktif melalui kegiatan penyuluhan dan pelatihan tentang pengembangan produk inovatif olahan hasil tambak oleh staf dosen bersama mahasiswa UPN Veteran Jawa Timur, bekerjasama dengan Pemda setempat dan Dinas Perdagangan dan Perindustrian Kodya Surabaya dalam wadah Program KKN PPM. Adapun tujuan kegiatan KKN PPM adalah melakukan penguatan dan pemberdayaan masyarakat petambak dalam mendukung usaha mandiri pengembangan produk inovatif olahan hasil tambak berbasis ekowisata mangrove.

\section{METODE PELAKSANAAN}

\section{Lokasi dan Sasaran Program}

Lokasi pelaksanaan Program KKN PPM ditetapkan di Kelurahan Keputih, Kecamatan Sukolilo Kota Surabaya. Penetapan lokasi kegiatan secara sengaja (purposive area) mempertimbangkan sebagian besar masyarakatnya bermata pencaharian sebagai nelayan dan petambak yang masih berada di ambang garis kemiskinan. Daerah Keputih juga berpotensi tinggi untuk dikembangkan ekowisata mangrove yang terbesar kedua setelah mangrove Wonorejo, sehingga melimpahnya plasma nutfah tersebut dilakukan peluang produk inovatif guna meningkatkan kesejahteraan ekonomi masyarakat.

a) Masyarakat Kelurahan Keputih Kecamatan Sukolilo selaku sasaran program, juga sebagai pelaksana kegiatan program diharapkan berpartisipasi secara aktif

b) Kepala Desa Keputih dan Camat Sukolilo selaku pendukung kegiatan program, dalam penyediaan sarana lokasi sasaran

Tabel 1. Potensi dan Permasalahan Kelompok masyarakat Sasaran

\begin{tabular}{|c|c|c|}
\hline Kelompok Masyarakat Sasaran & Permasalahan & Solusi \\
\hline \multirow{5}{*}{$\begin{array}{l}\text { Kelompok } \\
\text { Masyarakat Pesisir } \\
\text { Nelayan dan } \\
\text { Petambak }\end{array}$} & $\begin{array}{l}\checkmark \text { Kurangnya pemahaman bahwa } \\
\text { mangrove dapat memperbaiki } \\
\text { lingkungan khususnya mutu air } \\
\text { bagi kehidupan satwa air pantai dan } \\
\text { penahan abrasi }\end{array}$ & $\begin{array}{l}\checkmark \text { Perlu adanya pemahaman manfaat } \\
\text { mangrove melalui penyuluhan dan } \\
\text { pengelolaan mangrove pesisir }\end{array}$ \\
\hline & $\begin{array}{l}\checkmark \text { Masyarakat petambak masih } \\
\text { beranggapan bahwa tanaman } \\
\text { mangrove di tambak akan } \\
\text { menyulitkan pemeliharaan tambak, } \\
\text { dan kurangnya pemahaman bahwa } \\
\text { mangrove dapat memperbaiki } \\
\text { mutu air tambak yang baik bagi } \\
\text { kehidupan ikan }\end{array}$ & $\begin{array}{l}\checkmark \text { Perlu adanya pemasyarakatan } \\
\text { pentingnya konservasi kawasan } \\
\text { mangrove, program ini bagi } \\
\text { kehidupan manusia dan makhluk } \\
\text { hidup di sekitarnya juga untuk } \\
\text { menahan abrasi air laut dan } \\
\text { terjangan ombak besar, serta } \\
\text { perbaikan mutu air }\end{array}$ \\
\hline & $\begin{array}{l}\checkmark \text { Banyak tanaman mangrove yang } \\
\text { ditebangi untuk kayu bakar, } \\
\text { buahnya dibuang atau hanya untuk } \\
\text { mainan anak-anak }\end{array}$ & $\begin{array}{l}\checkmark \text { Pelatihan pemanfaatan hasil } \\
\text { tanaman mangrove menjadi produk } \\
\text { inovatif olahan hasil tambak }\end{array}$ \\
\hline & $\begin{array}{l}\checkmark \text { Berkurangnya hasil tambak } \\
\text { Kelurahan Keputih, padahal pernah } \\
\text { menjadi juara Kontak Tani dan } \\
\text { Nelayan Andalan }\end{array}$ & $\begin{array}{l}\checkmark \text { Perlu adanya pelatihan teknologi } \\
\text { budidaya tambak yang lebih baik, } \\
\text { dengan system mangrove }\end{array}$ \\
\hline & $\begin{array}{l}\checkmark \text { Masyarakat masih belum } \\
\text { memahami tentang strategi } \\
\text { pengembangan wirausaha, juga } \\
\text { belum memahami masalah } \\
\text { perijinan berusaha }\end{array}$ & $\begin{aligned} \checkmark & \text { Perlu adanya pelatihan } \\
& \text { kewirausahaan, pengembangan } \\
& \text { teknologi olahan produksi dan } \\
& \text { kemasan } \\
\checkmark & \text { Perlu diberikan pelatihan } \\
& \text { pengurusan perijinan }\end{aligned}$ \\
\hline
\end{tabular}


c) Dinas Perdagangan dan Perindustrian kota Surabaya sebagai lembaga mitra penyedia tenaga lapang dan pendamping masyarakat, juga pemberi ijin pengurusan legal perdagangan dan perindustrian pada produk inovatif olahan hasil tambak yang akan dihasilkan oleh masyarakat.

d) Mahasiswa UPN Veteran" Jawa Timur sebagai pelaku transformasi ilmu pengetahuan dan teknologi diharapkan bersedia mengabdikan ilmunya mengajak masyarakat berpartisipasi bersama-sama mendukung kegiatan usaha mandiri produk inovatif olahan hasil tambak

e) DPL sebagai pendamping transfer inovasi ilmu pengetahuan dan teknologi

f) LPPM UPN "Veteran” Jawa Timur sebagai pelindung kegiatan KKN-PPMb secara keseluruhan

\section{Persiapan}

Konsep pemberdayaan masyarakat menekankan pada kegiatan penyuluhan dan pelatihan, beberapa mekanisme persiapan kegiatan KKN-PPM mencakup:

1. Tutorial materi ke mahasiswa peserta $\mathrm{KKN}$ selama 4 hari, setiap 2 sub program dilakukan setiap hari (sebelum pelaksanaan program) materi yang disampaikan antara lain:

$\checkmark$ Reboisasi hutan mangrove, jenis tanaman dan cara penanaman, serta manfaat hutan mangrove,

$\checkmark$ Pengembangan tambak dengan system mangrove,

$\checkmark$ Pengelolaan lingkungan pantai dengan penanaman mangrove,

$\checkmark$ Pengembangan produksi hasil laut/tambak dan olahannya,

$\checkmark$ Pengembangan hasil olahan tanaman mangrove

$\checkmark$ Kewirausahaan.

2. Peragaan dan contoh penggunaan alat yang sesuai dengan sub program mahasiswa peserta KKN.

3. Pendampingan peserta KKN ke lokasi sasaran sesuai dengan plotting sub program selama kurang lebih satu bulan.

4. Pengurusan ijin Perdagangan dan Perindustrian bagi produk inovatif unggulan sehingga dapat dipasarkan secara legal.

\section{Waktu Pelaksanaan}

Kegiatan KKN PPM dilaksanakan mulai tanggal 1 Juli02 Oktober 2013 dan 1 Juli - 02 Oktober 2015. Rancangan kegiatan KKN PPM disesuaikan dengan kondisi dan lingkungan sekitar lokasi berdasarkan hasil observasi yang telah dilakukan agar kegiatan individu ini dapat berjalan efektif dan efisien dari segi waktu, tenaga, pikiran, materi, serta urgenitasnya.

\section{HASIL PELAKSANAAN}

KKN - PPM dengan Tema "Penguatan Dan Pemberdayaan Masyarakat Petambak Dalam Mendukung Usaha Mandiri Pengembangan Produk Inovatif Olahan Hasil Tambak di Kelurahan Keputih Kecamatan Sukolilo Kodya Surabaya" memiliki target untuk mengangkat produk-produk olahan masyarakat Keputih menjadi produk inovatif yang mampu menembus pasar sehingga bisa meningkatkan kesejahteraan masyarakat, dengan beberapa hasil pelaksanaan yang telah dilaksanakan antara lain:

1. Sosialisasi Pemberdayaan Masyarakat Pesisir dalam Mendukung Usaha Mandiri Berbasis Ekowisata Mangrove, Pengembangan Grand Design, dan Green and Clean Kawasan Ekowisata Mangrove.

Materi ini merupakan hasil utama ditargetkan dari KKN PPM ini yang disosialisaikan kepada masyarakat Keputih sebanyak minimal 20 orang setiap kali pertemuan seminggu 3 kali, dilaksanakan di Griyo Keputih (Gambar 1). Masyarakat dapat menerima program pengembangan kawasan wisata mangrove di Kelurahan Keputih menjadi suatu kawasan usaha mandiri. Selain itu pemahaman masyarakat terhadap pengembangan kawasan wisata mangrove menjadi suatu kawasan usaha mandiri, dengan tetap mempertahankan kawasan wisata yang berbasis pada pemeliharaan lingkungan tampak meningkat. Hal ini terlihat dari antusias masyarakat Keputih Kecamatan Sukolilo pada saat sosialisasi.

Sosialisasi pentingnya tanaman mangrove dilaksanakan kepada masyarakat Keputih khususnya Bapak-bapak yang merupakan nelayan dan petambak karena merekalah yang sehari-hari berhubungan langsung dengan tanaman mangrove (Gambar 1). Masyarakat pesisir Keputih Kecamatan Sukolilo telah menyadari adanya kerusakan kawasan hutan mangrove di lingkungan mereka karena dieksploitasi secara liar yang menyebabkan produksi ikan dan kepiting mereka berkurang, dan mereka sudah meminta kepada Pemerintah Daerah untuk mengembalikan kondisi kawasan mangrove mereka seperti semula. Namun kurangnya kepercayaan diri dan kemampuan berusaha mereka menyebabkan mereka belum mampu bergerak sendiri (Riski, 2012). Sosialisasi pentingnya tanaman mangrove telah dilaksanakan dan tampak bahwa masyarakat petambak dan nelayan mengerti pentingnya melestarikan tanaman mangrove. Bahkan mereka bersedia melaksanakan reboisasi hutan mangrove dengan menyediakan lahan bagi pembibitan tanaman mangrove.

Pemahaman masyarakat terhadap pengembangan kawasan wisata mangrove menjadi suatu kawasan usaha mandiri, dengan tetap mempertahankan kawasan hutan mangrove akan meningkatkan wawasan mereka sekaligus menimbulkan semangat untuk ikut berpartisipasi melestarikan dan mengembangkannya. 
Materi Green and Clean Kawasan Ekowisata Mangrove memberikan pengertian dasar kepada masyarakat bahwa kebersihan dan keindahan merupakan hal penting untuk membangun suatu kawasan ekowisata yang bisa menarik minat masyarakat lain untuk datang ke lokasi tersebut. Penyuluhan tentang Green and Clean Kawasan Ekowisata Mangrove ini juga dilakukan oleh mahasiswa dengan mendatangi rumah ketua atau pemuka kelompok masyarakat, dan mengundang anggotanya.

2. Pembuatan Alat Penjernih Air

Pembuatan alat penjernih air, dengan maksud mengubah air tambak menjadi air bersih yang bisa digunakan untuk cuci tangan dan kaki. Alat Penjernih yang dibuat ini merupakan alat yang sederhana dan portable atau bisa dibawa kemana-mana, sehingga alat ini bisa dibuat oleh para petambak dan nelayan. Alat penjernih air ini merupakan alat sederhana yang dibuat dengan maksud menumbuhkan kreativitas dan semangat petambak dan nelayan setempat untuk melakukan suatu usaha penjernihan air untuk mendukung pengembangan kawasan ekowisata di Kelurahan Keputih.

Alat dan Bahan yang digunakan adalah Tong air, kran air, pasir, pasir silika, kerikil, arang, spon/ijuk/kapas filter, pipa PVC $3 / 4$, kapas, lilin, korek api, obeng, gunting, bensin. Cara membuat alat ini sangat mudah yaitu memasang kran air pada bagian bawah tong untuk mengalirkan air bersih hasil penjernihan, kemudian bahan-bahan penjernih dimasukkan dan ditata ke dalam tong secara berurutan sebagai berikut pertama atau paling bawah adalah pasir kemudian pasir silika, kemudian kerikit, selaNjutnya arang, kemudian spon dan terakhir kapas (Gambar 2 dan 3).

3. Pelatihan Pembuatan Tepung dari Buah Mangrove Buah mangrove yang dapat dibuat tepung ada 4 jenis yaitu Bruguiera gymnorrizha, Bruguiera cylindrica, Sonneratia alba, dan Sonneratia caseolaris. Bruguiera gymnorrizha mempunyai rangkaian bunga 1 dan kelopak bunganya berwarna merah, sedangkan Bruguiera cylindrica mempunyai rangkaian bunga 3 dan kelopak bunganya berwarna putih. Sonneratiav alba bunganya mempunyai benangsari berwarna putih dengan tangkai buah pendek dan kelopak buah mengarah ke bawah, sedangkan Sonneratia caseolaris bunganya mempunyai benangsari berwarna merah dengan tangkai buah panjang dan kelopak buah mengarah ke atas.

Prosedur pembuatan tepung dari buah jenis Bruguiera sebagai berikut. Buah dikupas kulitnya kemudian daging buah dicincang, dicincang direndam selama 3 hari dengan air biasa (air diganti setiap hari) untuk mengurangi kandungan tanin. Bisa juga dilakukan dengan mencuci dan diremas-remas kemudian direbus dengan air yang telah mendidih sambil diaduk kurang lebih 20-30 menit. Buah yang telah direndam atau direbus, selanjutnya dicuci dengan air biasa sambil diuleni, dijemur di bawah sinar matahari kurang lebih hingga 1 hari atau bisa menggunakan pengering kabinet. Setelah kering, bila ingin langsung dijadikan nasi maka direndam 10 menit, kemudian ditanak. Jika ingin dijadikan tepung, buah bisa langsung digiling dengan menggunakan blender kemudian diayak. Tepung yang dihasilkan dapat digunakan sebagai bahan dasar pembuatan roti atau produk pangan lainnya.

4. Pembuatan Alat Pengering Bubur Buah Mangrove Menjadi Tepung

Alat Pengering Bubur Buah Mangrove menjadi Tepung direncanakan dibuat pada saat kami mencoba membuat tepung dari buah mangrove sebelum KKN PPM dimulai. Alat ini terbuat dari besi, menyangga lebih kurang 12 buah nampan plastik tempat pengeringan bubur buah mangrove (Gambar 6.). Penggunaan alat ini mudah, yang penting penempatannya harus seimbang sehingga alat tidak runtuh. Alat pengering bubur buah mangrove dapat dikeringanginkan dengan lebih aman, tidak takut kotor atau terkena debu dan dijarah binatang.

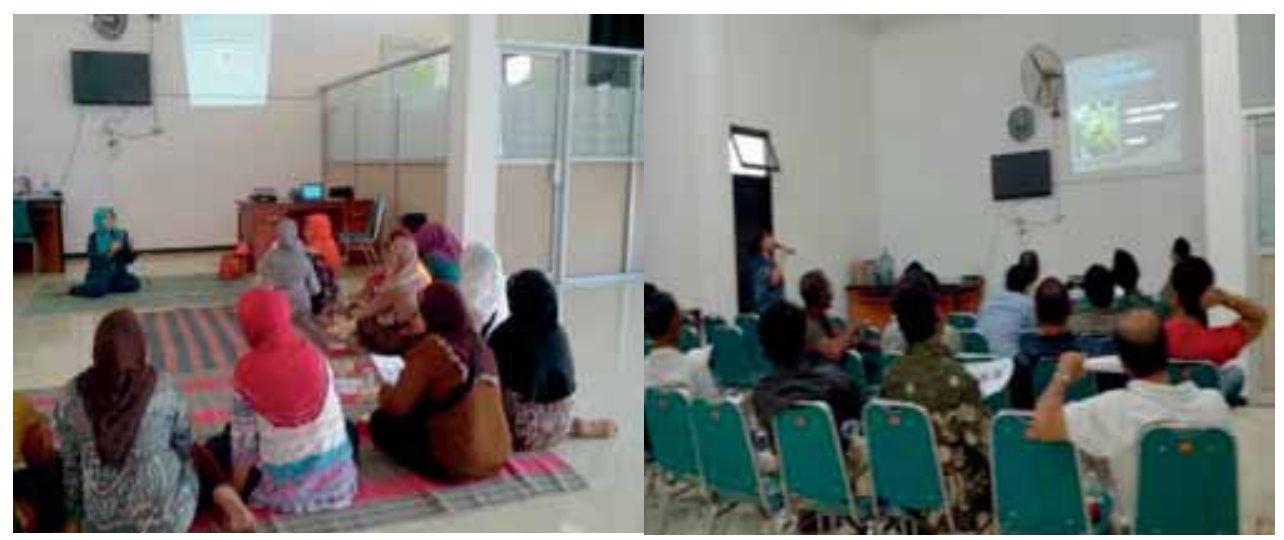

Gambar 1. Sosialisasi Pemberdayaan Kawasan Ekowisata Mangrove. 


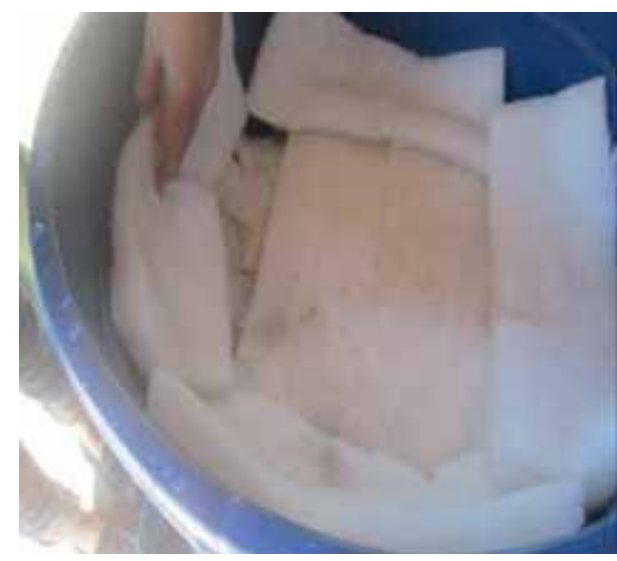

Gambar 2. Pembuatan Alat Penjernih Air Sederhana

\section{Pelatihan Pembuatan Bakso Bandeng, Bakso Udang, dan Bandeng Asap}

Pelatihan pembuatan bakso bandeng, bakso udang, dan bandeng asap dimaksudkan untuk menambah nilai jual hasil tambak yang cukup melimpah di Kelurahan Keputih, karena untuk pembuatan makanan olahan tersebut terutama bakso bisa digunakan hasil tambak yang bentuk atau ukurannya tidak diinginkan atau merupakan hasil sortiran tetapi masih bagus kondisinya. Pengolahan makanan tersebut dengan kemasan yang bagus dapat dijadikan buah tangan apabila kawasan Keputih telah berkembang menjadi kawasan ekowisata.

Mendukung olahan bandeng asap maka, program KKN PPM ini juga melakukan pembuatan alat pengasapan ikan. Pembuatan alat pengasapan ikan ini (Gambar 8.) diharapkan masyarakat Keputih dapat terinspirasi untuk membuat beraneka lahan makanan yang dapat menambah nilai jual hasil tambaknya.

\section{Penanaman Bibit Mangrove}

Penanaman 2,000 bibit mangrove di tambak pesisir Keputih dilaksanakan dengan melibatkan mahasiswa peserta KKN PPM sebanyak 50 mahasiswa dan mahasiswa baru Fakultas Pertanian sebanyak 100 mahasiswa, beserta

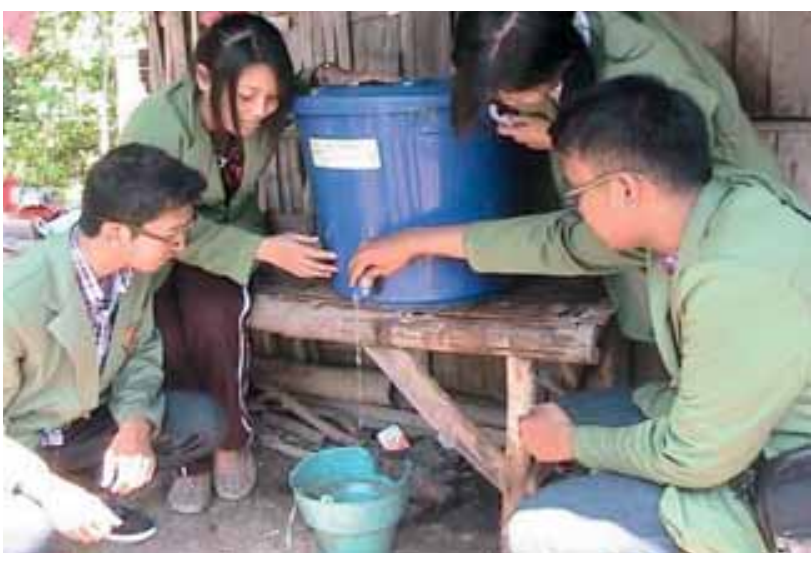

Gambar 3. Uji Coba Hasil penjernihan air tambak menjadi lebih jernih

sekitar 15 orang pejabat di Lingkungan UPN Veteran Jawa Timur, serta 25 orang masyarakat Kelurahan Keputih. Pelaksanaan penanaman dipimpin langsung oleh Rektor UPN Veteran Jawa Timur, bersamaan dengan acara Sepeda Pagi Bersama. Penanaman pada pagi hari dipimpin oleh Rektor UPN Veteran tersebut berlangsung simbolis selanjutnya penanaman dilakukan oleh tenaga penanam dari masyarakat Keputih.

Setelah penanaman mangrove dilaksanakan Lomba memasak Hasil Tanaman Mangrove dan Hasil Tambak untuk ibu-ibu PKK di kelurahan Keputih yang dihadiri oleh Rektor UPN "Veteran" JATIM dilaksanakan setelah kegiatan penanaman mangrove. Masyarakat Keputih Tampak antusias mengikuti semua kegiatan. Bahkan salah satu dari pemuka masyarakat Keputih bersedia menyediakan lahan untuk Tempat Pembibitan Mangrove di Kelurahan Keputih, sehingga masyarakat Keputih dapat mempraktekkan pembibitan mangrove. Masyarakat dan kami pelaksana KKN PPM berharap ada program hibah yang dapat membantu masyarakat Keputih untuk mewujudkan rencananya membuka Pembibitan mangrove.

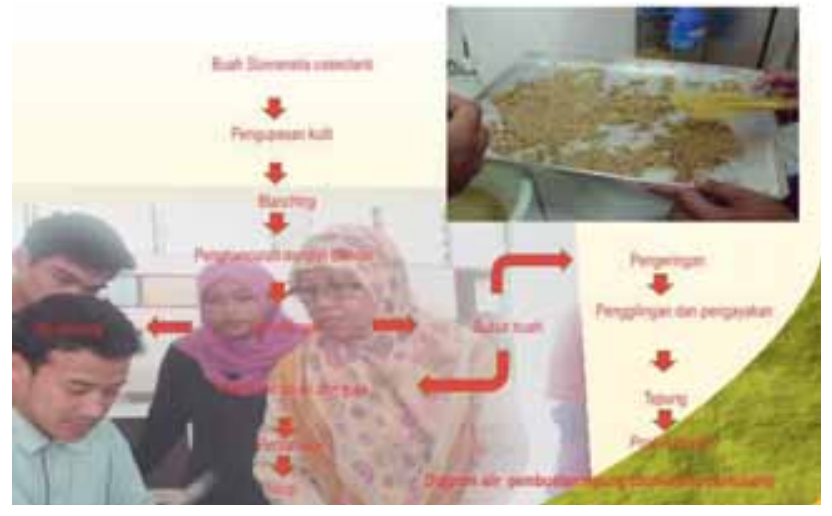

Gambar Proses Pembuatan Tepung dari Buah Mangrove.

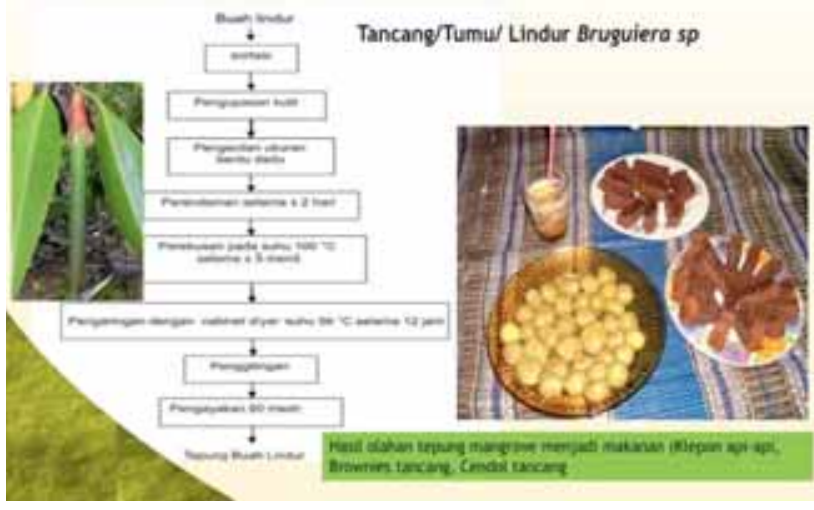

Gambar 4. Olahan Tepung Mangrove. 


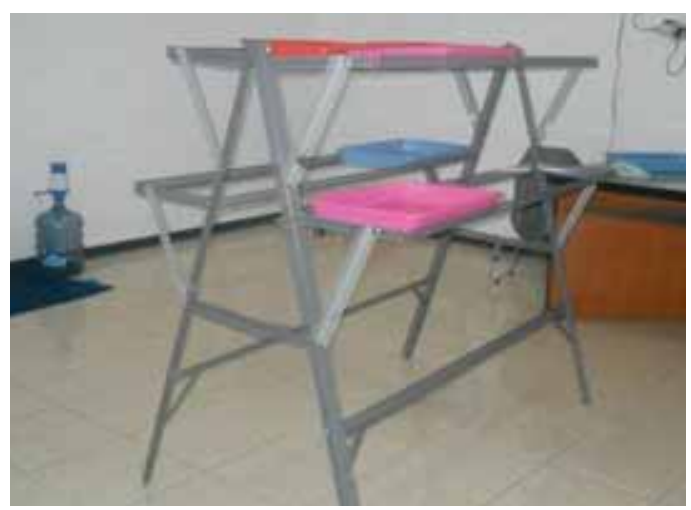

Gambar 5. Alat Pengering Bubur Buah Mangrove.

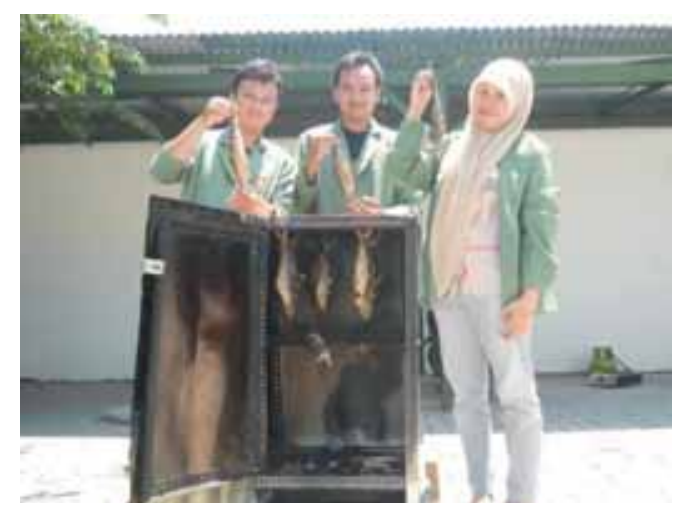

Gambar 7. Alat Pengasapan Bandeng.

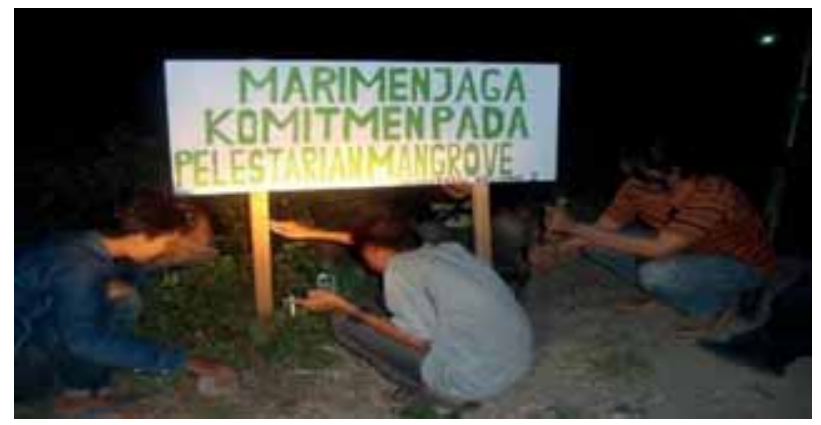

Gambar 8. Slogan Pelestarian Mangrove yang dipasang di sekitar Tambak Keputih.

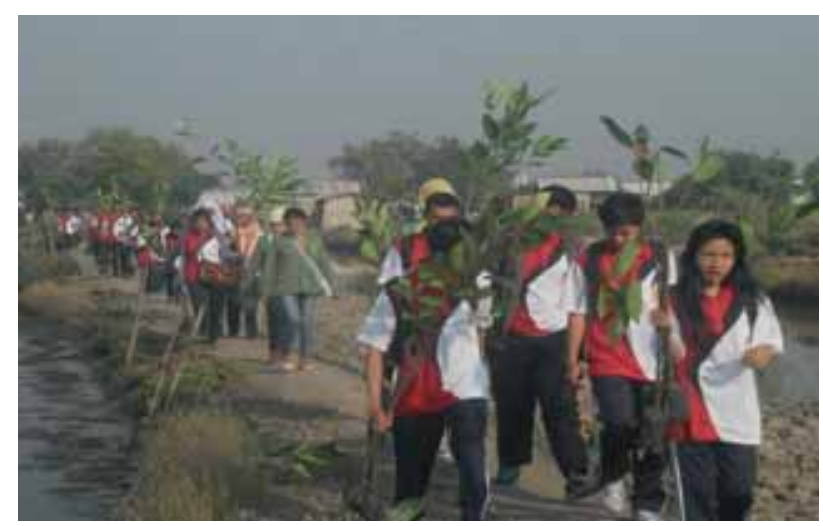

Gambar 10. Mahasiswa Baru Fakultas Pertanian mengikuti kegiatan Penanaman Mangrove.

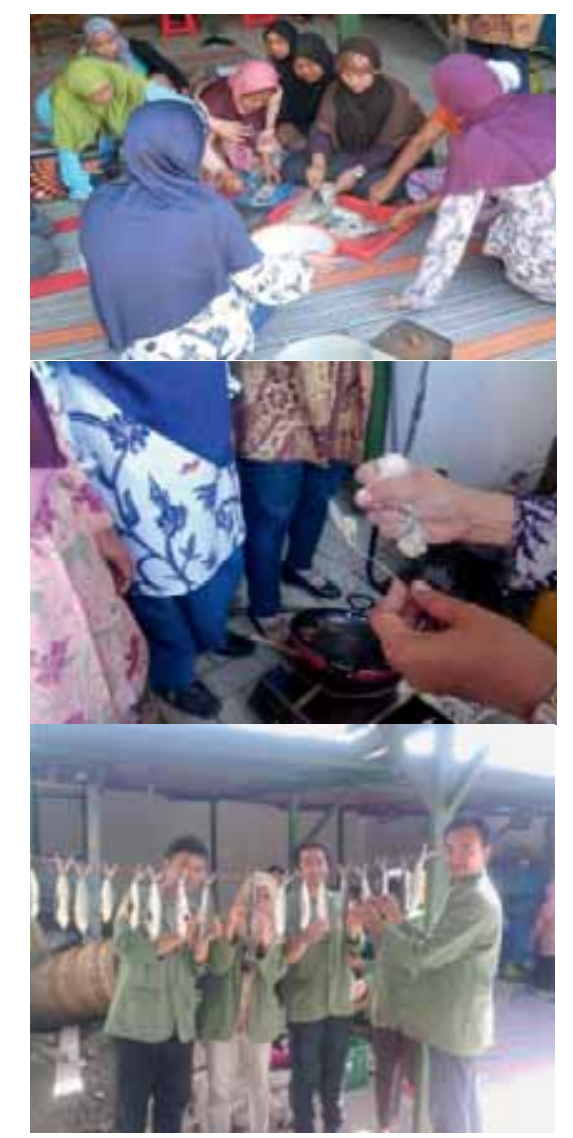

Gambar 6. Berbagai Pelatihan Olahan Hasil Tambak

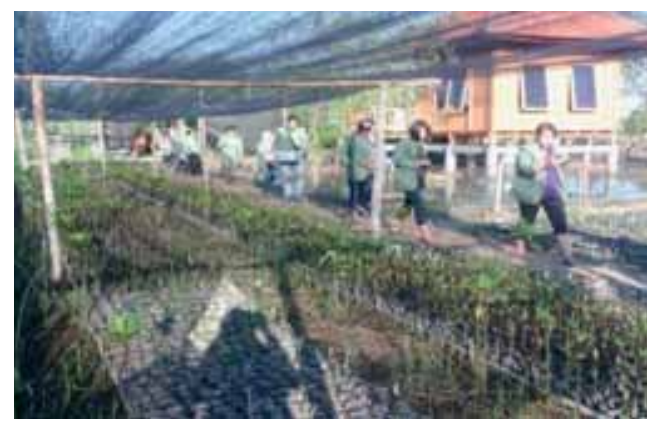

Gambar 9. Mahasiswa dan Masyarakat Keputih praktek penanaman bibit mangrove.

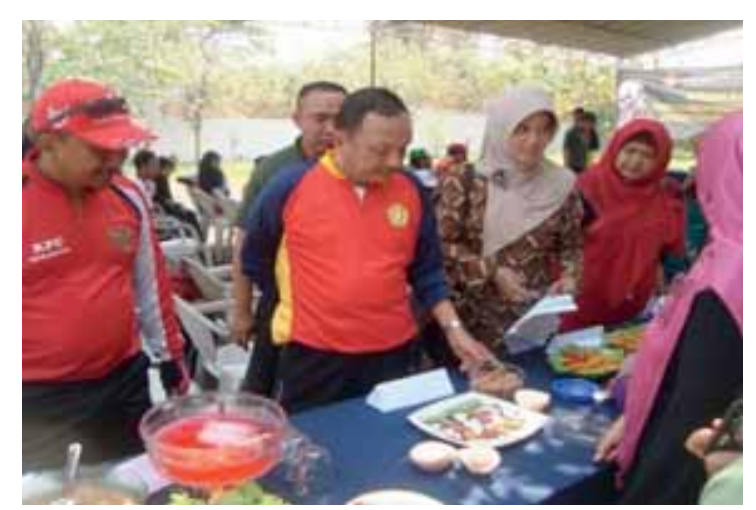

Gambar 11. Rektor UPN "Veteran” Jawa Timur melakukan penilaian kreatifitas ibu-ibu PKK. 


\section{SIMPULAN}

Kegiatan KKN - PPM yang dilaksanakan di Kelurahan Keputih, Kota Surabaya diimplementasikan ke dalam berbagai capaian kegiatan. Keberhasilan kegiatan dapat dijelaskan sebagai berikut:

1. Masyarakat Pesisir Keputih baik nelayan, petambak maupun masyarakat biasa sangat antusias menerima penyuluhan dan pelatihan yang dilaksanakan selama KKN PPM.

2. Produk inovasi yang diberikan kepada masyarakat seperti Alat Penjernih Air, Alat Pengering Bubur Buah Mangrove, dan Alat pengasapan ikan serta pengetahuan beberapa olahan mangrove dan hasil tambak dibutuhkan masyarakat untuk mengembangkan potensi usaha mandiri dalam mendukung terciptanya kawasan ekowisata berbasis Mangrove Keputih, Kota Surabaya.

Saran yang dapat direkomendasikan terkait dengan pelaksanaan program ini adalah, memberi ruang beragam kemitraan, baik antar institusi produksi pertanian, institusi keuangan maupun institusi pemerintah serta kerja sama kemitraan demi terwujudnya ekowisata berbasis ekosistem mangrove sekaligus meningkatkan pendapatan masyarakat.

\section{DAFTAR PUSTAKA}

Anwar, C. 1998. Akumulasi di Bawah Tegakan Mangrove. Prosiding Expose. Hasil

Penelitian BTPDAS Surakarta, Februari 1998: 105-115. BTPDAS. Surakarta, Solo.

Anwar, C. 2005. Wanamina, Alternatif Pengelolaan Kawasan Mangrove Berbasis Masyarakat. Prosiding Ekspose Hasil Penelitian Pemanfaatan Jasa Hutan dan Non Kayu Berbasis Masyarakat sebagai Solusi Peningkatan Produktivitas dan Pelestarian Hutan, Cisarua, 12 Desember 2003: 21-26. Pusat Litbang Hutan dan Konservasi Alam, Bogor.

Anonim, 2012, Surabaya Tuan Rumah Seminar Kerusakan Kawasan Mangrove. http://surabaya1.com/berita/6682. html. Diakses 6 Januari 2014.

Nugrahanti, I.M., 2012. Pengembangan Permukiman Nelayan di Pantai Timur Surabaya. http://digilib.its.ac.id/public/ ITS-paper-23646-3608100068-Presentation.pdf.

Wiyatiningsih, Sri., 2013. Pemberdayaan Masyarakat Pesisir Dalam Mendukung Usaha

Mandiri Berbasis Ekowisata Mangrove di Kelurahan Keputih Kecamatan Sukolilo. 